\title{
Age-related foraging behaviour in honey bees under artificial conditions
}

\author{
MH Pham-Delègue *, M Le Métayer, P Douault, C Masson \\ INRA-CNRS (URA 1190), Laboratoire de Neurobiologie Comparée des Invertébrés, \\ 91440 Bures-sur-Yvette, France
}

(Received 31 May 1989; accepted 24 January 1990)

\begin{abstract}
Summary - The distribution of foraging among 4 worker groups of different ages was observed in a flight room. Foraging was mostly performed by the oldest workers, who came to forage first and were the most numerous. Workers from the other groups visited the feeding station infrequently until the second half of the observation period, then increased their visits. Regardless of their age group, each individual coming to forage performed a constant average level of activity, despite some variability in the individual scores of visits. These experiments stressed a strong intra-age group interaction among a population of potential foragers, and allowed us to record data on both group and individual strategies. In conjunction with studies performed under natural conditions, our experiments conducted under artificial conditions may contribute to the analysis of some basic parameters of foraging behaviour.
\end{abstract}

Apis mellifera (ligustica $x$ caucasica) $x$ mellifera / foraging / age effect / division of labour / flight room

\section{INTRODUCTION}

In the normal ontogeny of honey bee tasks, younger workers are devoted to hive duties and older workers perform foraging (Rösch, 1925, 1930; Ribbands, 1952; Lindauer, 1953; Sekiguchi and Sakagami, 1966; Michener, 1974; Seeley, 1982; Winston and Punnett, 1982; Kolmes, 1985). However, it is known that there is considerable flexibility in the ages at which workers shift from hive to field duties, depending on internal colony requirements or external conditions. Through experiments where specific groups of the worker population were removed, it was well demonstrated that workers could shift from one task to another (Rösch, 1930; Lindauer, 1961; Kolmes, 1985; Winston and Fergusson, 1985). These efforts, as well as that of Seeley (1982) who tested predictions about the design of the age polyethism schedule for labour inside the hive, were concerned with the shift of workers duties. Little time was devoted to analyzing the division of labour among workers all performing the task of foraging, except Seeley (1983) who explored division of labour between scouts and recruits in honey bee foraging, to determine the

* Correspondence and reprints 
ecological significance of the dance language.

In this paper, we aim to detail the intergroup or inter-individual distribution of the foraging task among a population of known age foragers. We have measured the distribution among groups of foragers of closely related ages to assess the degree of flexibility of such a task under controlled conditions.

\section{MATERIALS AND METHODS}

The experiments were conducted under artificial conditions to control the constitution of the experimental colony and to standardize the observation procedure. The experiments were carried out in a flight room of $12 \mathrm{~m}^{3} \mathrm{vol}$, as described by Douault (1978). The light intensity was 300 lux with a $12 \mathrm{hr}$ day - $12 \mathrm{hr}$ night photoperiod. The temperature was $24 \pm 2{ }^{\circ} \mathrm{C}$ with $55 \%$ relative humidity. The air in the room was renewed regularly ( 5 times per $h$ ).

Experiments were conducted with a colony of 3-strain hybrid Apis mellifera (ligustica $x$ caucasica) $x$ mellifera which produce high honey yields under natural conditions (Fresnaye et al, 1974; Comuet and Fresnaye, 1979), and which is known to exhibit a high level of foraging under artificial conditions (Pham-Delegue et al, 1984).

The colony was first constituted of unknown age winter worker bees, and later replaced by age-marked workers: a 2-year old queen with a cluster of 150 worker bees of unknown age were first introduced in the experimental hive $(21 \times 21.5 \times 27 \mathrm{~cm})$, set with 5 empty combs and 1 comb filled with food; these escort bees were later removed when arriving at the feeding device. Four samples of new born worker bees were successively introduced, leading to a range of $\mathbf{4}$ groups of workers differing in age by $14 \mathrm{~d}$ from the first group introduced to the preceeding one: group I (400 individuals), group II (310 individuals) introduced $3 \mathrm{~d}$ later, group III (440 individuals) introduced $5 d$ later than group II, group IV (800 individuals) introduced 6 d later than group III. Each age group was identified by a different coloured spot painted on the thorax of the workers.
The foraging behaviour was observed on a feeding device (Pham-Delegue and Masson, 1985). This device provided sources of sugar solution associated with a scent. A $50 \%$ sucrose solution, known to be highly acceptable to honey bees (Waller, 1972), was given as a reward. The associated scent was geraniol $1 \%$ in paraffin oil. Six scented feeders were distributed on a slowly rotating device $(1 / 3 \mathrm{rpm})$. Such a device attracts a high number of foragers which can be fed simultaneously.

The experimental device was positioned at $1.50 \mathrm{~m}$ from the hive entrance every day between 2 and $4 \mathrm{pm}$. To maintain the motivation to search for food, at times other than the 2-4 pm period, the honey bees were fed at the same location with a $50 \%$ sucrose solution and a dish of pollen at all times. No additional food was given in the hive.

The device was presented every day following the introduction of the last age group, but the data reported below begin with the first spontaneous landing on the device. Thus, the observations started $31 \mathrm{~d}$ after the introduction of the first group of workers in the hive and the experimental period ended 38 d later.

The observation procedure was as follows: within the experimental period, each agemarked bee was collected at its first landing on a feeder and individually labelled with a numbered tag according to its rank of landing. Every $15 \mathrm{~min}$, the identity (colour and number) of the foragers on the device was recorded, up to 8 recordings per observation day. Experiments were carried out daily, with several days of disruption, leading to $22 \mathrm{~d}$ of observations. Mortality was noted every observation day by collecting dead bees on the floor of the flight room.

\section{RESULTS}

During the experimental period the $\%$ cumulative mortality per group according to age (ie number of dead workers, including foragers and non-foragers, versus the initial number of workers $\times 100$ ), increased similarly; regardless of the group, all points fitted with a curve $(y=0.71 \exp (0.07 x))$, with a highly significant level of correlation 
( $r=0.97,82 \mathrm{df}$ ). Until $35 \mathrm{~d}$ old, mortality was of 0-5\%; between $35-70 \mathrm{~d}$ old, mortality increased linearly from $5-65 \%$.

Since the mortality was approximately equivalent in every group, it did not affect the foraging activity differentially among each group. Thus, this activity was reported as the daily percentage of new foragers (the number of new foragers is cumulated every observation day) versus the initial number of workers (eg, 400 in group I), as a function of age (fig 1). The age when the first member of a group performed its first foraging trip was, respectively, $32,33,28$, 18 day old for groups I, II, III and IV. Workers from group IV was recorded simultaneously; workers from groups II and III appeared at the third observation day. At the end of the experiment, workers were still foraging at an age of $71,68,63,57$ day re- spectively, for the oldest foragers from groups I, II, III, IV. The statistical comparison of the proportions, within the common age-range when the 4 groups were present (from 33-57 day old), showed that the foraging activity was significantly higher in group I than in the other groups (2tailed, signed ranks Mann-Whitney test, $P<0.01$ ); the activity in group II was lower than in group IV $(P<0.05)$. The highest proportion of foragers from group I reached the value of $30 \%$ workers dedicated to foraging at the end of the experiment; bees from the 3 other groups were involved in foraging with maximum values of $11-13 \%$; group II being the least represented. At the end of the experiment, groups I and II, whose foragers were the oldest, reached a steady state, while the number of foragers was still increasing among groups III and IV.

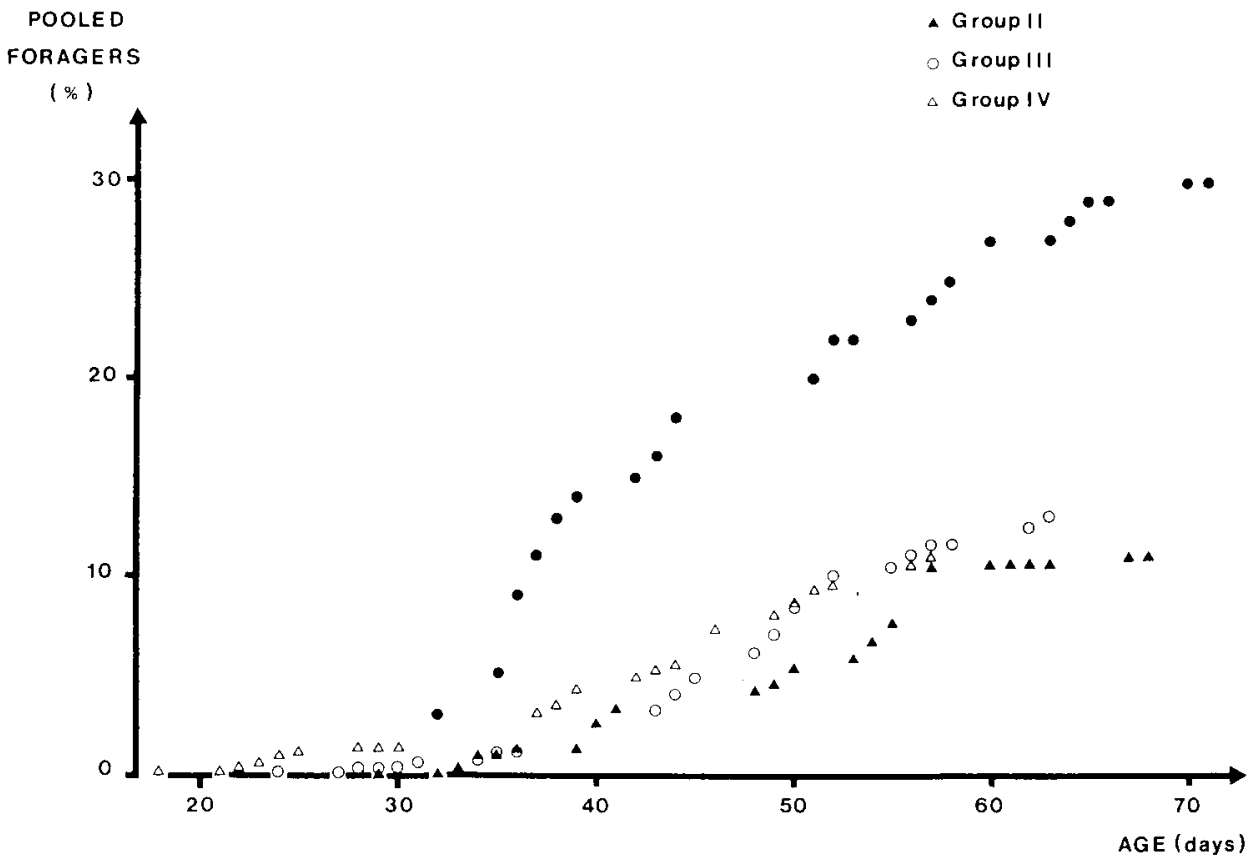

Fig 1. Foraging curves of the different age groups as the daily percentage of new foragers (cumulated every observation day) versus the intial number of foragers, as a function of age. 
Consistent with the fact that foragers from group I were the most numerous, they were the most active until the 10th observation day (performing more than $75 \%$ of the visits), and were then progressively replaced by the other groups, to a final level of $16.3 \%$ visits in group I, $14.2 \%$ in group II, $25.5 \%$ in group III, $43 \%$ in group IV, at the 22nd observation day. The highest number of visits was 245 (6th observation day), 63 (16th observation day),
80 (17th observation day), 106 (17th observation day), respectively, for groups I, II, III, IV.

Considering the individual activity according to age group, by reporting the number of visits per observation day as a function of particular individuals performing these visits (fig 2), no difference appeared between the groups. Globally, the number of visits was positively correlated with the

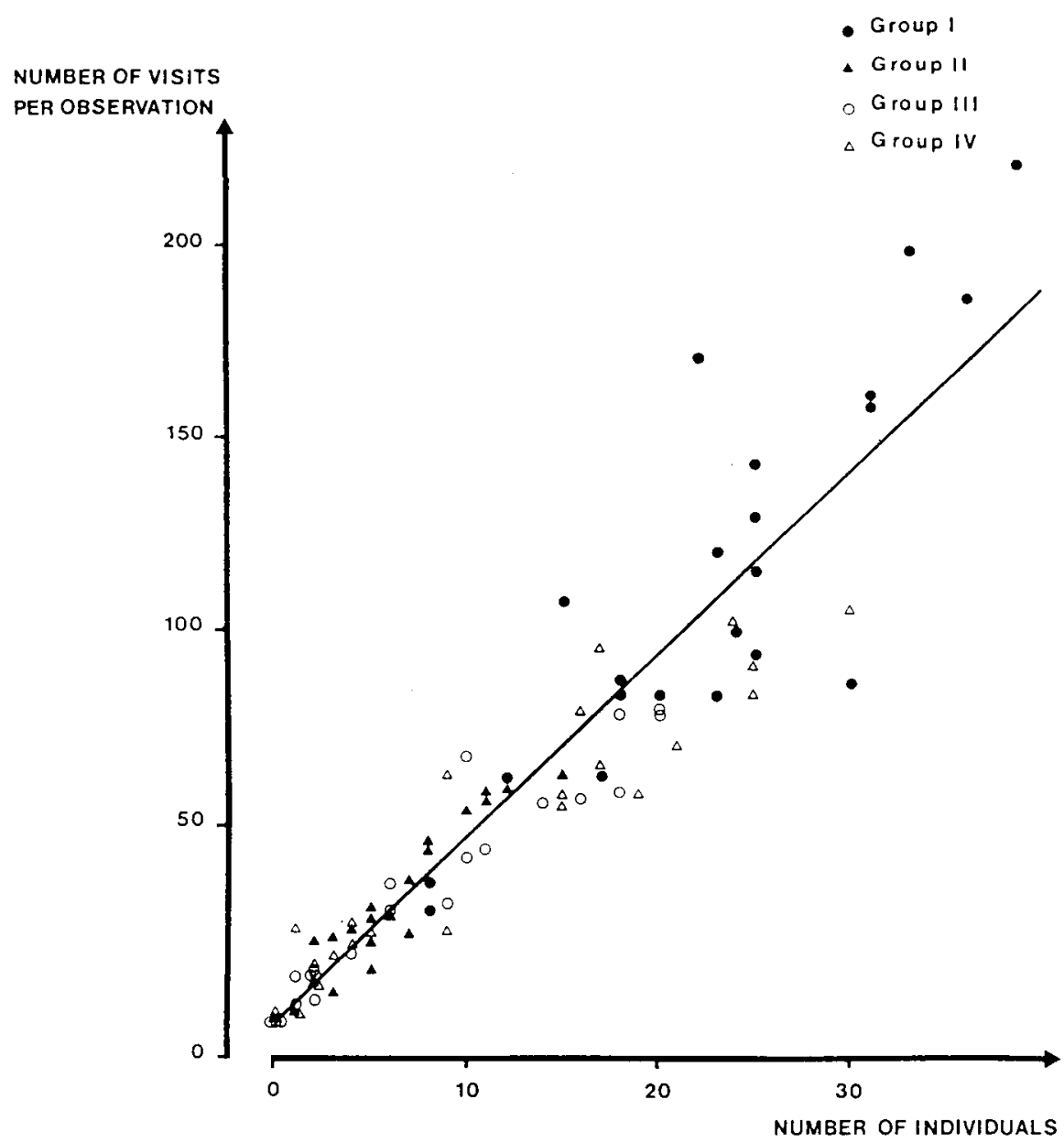

Fig 2. Level of foraging activity of each age group as the number of visits per observation day according to the number of individuals performing these visits. Equation of the linear regression: $y=4.74 x-$ 1.17 . 
number of individuals $(r=0.93,86 \mathrm{df}, P<$ $0.001 ; y=4.74 x-1.17$ ). Thus, each individual performed the same average number of 4.74 visits per observation day, whatever group it came from. However, a maximum value of 38 individuals from group I were foraging simultaneously, while a maximum of 15 foragers appeared from group II; values from group III (20 indivudals) and IV (30 individuals) were intermediate. Also the highest number of foragers appeared earlier in group I (7th versus 16th observation day in the other groups).

To focus on the individual strategy of foraging, we detailed the behaviour of 84 individually-marked foragers from group I. The faithfulness to the food source was evaluated by recording the number of ob-

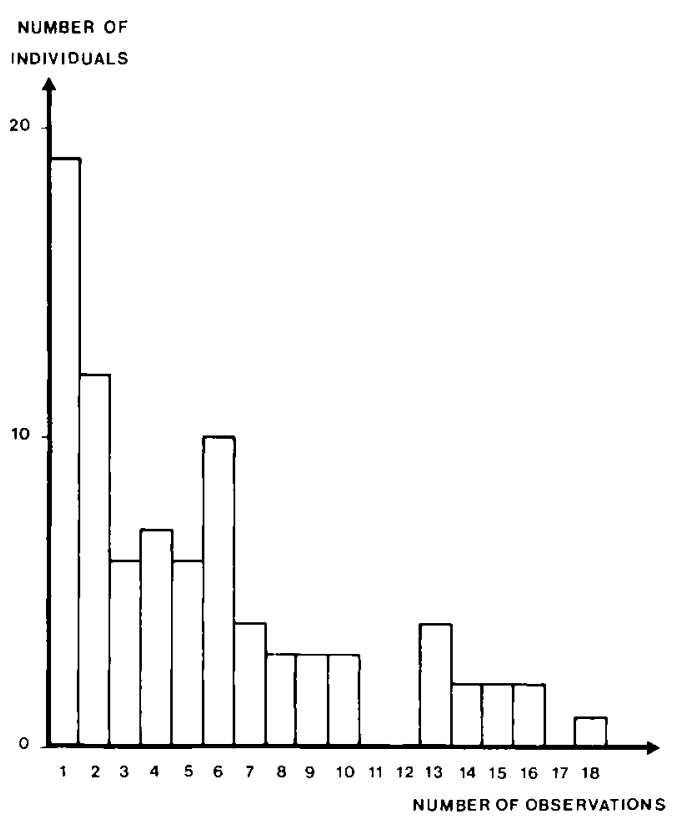

Fig 3. Faithfulness to the food source as the distribution of the foragers from group I $(N=84)$ according to the number of observation days when they were present over the experimental period (22 d). servation days when each individual came to forage (fig 3). Over 22 observation days, 19 foragers were observed only once and did not come on the following observation days. Groups of 6-12 workers came to forage on 2-6 d of observations. Fewer foragers were observed over longer periods. Thus, the faithfulness to the food source was relatively weak for group I. Moreover, the number of visits exhibited by foragers of different groups was identical. These results could explain the fact that, despite the larger number of foragers in group I, the other groups reached the same level of activity at the end of the experiment.

\section{DISCUSSION}

These experiments were conducted under artificial conditions, which allowed us to work throughout the year and to control the environment. These conditions did not strongly affect the life span of the workers. Mortality was slightly higher than under natural conditions (65\% after 2 months versus $50 \%$ for winter bees, according to Fukuda and Sekiguchi, 1966), probably due to the intense flight activity artificially maintained in cage conditions. Moreover, the foraging age closely matched the values mentioned under natural conditions; various studies have shown that the means for first foraging flights range from 18-43 $d$ (reviewed by Michener, 1974; Winston and Punnett, 1982; Kolmes, 1985). However, it must be noted that in our experiment, the youngest workers which came to forage (18 d old) were coming from the largest group (group IV). This may result from either a higher inter-individual stimulation of being in a large group, or a higher probability of at least 1 bee leaving in large groups.

During the first half of the observation period, foraging was mostly performed by 
workers from the oldest age group, which is consistent with many studies showing that tendency to forage is a positive function of age (Rösch, 1925, 1930; Ribbands, 1952; Lindauer, 1953; Sekiguchi and Sakagami, 1966; Michener, 1974; Seeley, 1982; Winston and Punnet, 1982; Kolmes, 1985). However, it is surprising that this activity is restricted to a particular age pool (group I), when the other groups of quite similar age (at least group II) had already appeared and may have participated in this task more actively. This may be due to a particular physiological fitness or to a higher motivation "to go" or "to stay" (Nunez, 1970) within this group of workers. It is known that foraging is performed by specific groups of workers among a population of potential foragers (Ribbands, 1954; von Frisch, 1967; Wenner et al, 1967), and here it may be suggested that this role-subdivision relies on a sharp age effect; this implies a strong intra-age group foraging stimulation and a possible inter-group inhibition. Further observations of the communication processes inside the hive are required to point out the degree of intra- or inter-group relations and the ability of workers to identify members of their own group.

Even though there is a differential contribution of each age group to forage according to the number of foragers, it appears that whenever an individual worker from any group comes to the feeding station, it exhibits a constant average level of activity, expressed as the number of visits per observation day. However, when considering the level of activity as the faithfulness to the food source, individual strategies differed strongly; numerous individuals foraging on 1 day only. These individuals might account for a group of "lazy" bees, who fulfilled an important function in the hive, according to Lindauer (1953). These individuals might also shift to hive duties, as described after extreme demographic manipulations (Rösch, 1930;
Lindauer, 1961; Kolmes, 1985; Winston and Fergusson, 1985). Manipulations closer to the normal variations that could occur during the annual cycle of a honey bee colony, such as those conducted by Kolmes and Winston (1988), might lead to a different task distribution, even under artificial conditions.

In conclusion, although these experiments were carried out under artificial conditions and do not allow us to directly relate the observations to normal outdoor foraging conditions, they do allow the separate control of parameters affecting the foraging task. Here, using controlled age groups, it appeared that age effect is of major importance since bees seemed to interact more with bees of the same age (within group I) than with bees of other ages (group I - group II). The flexibility in the temporal division of labour schedule, shown under natural conditions by removing groups of workers more or less in the range of variations normally experienced by a colony, could be tested in the flight room by constituting colonies of entirely known age workers. Moreover, the colony requirements (linked to the brood amount and the food available inside the hive), as well as the parameters of the feeding source (eg, the quantity and/or quality of the food, the way it is distributed, the olfactory or visual cues associated to it, etc) could be easily controlled under artificial conditions. Also, the observation of interindividual communication processes inside the hive could be facilitated. Therefore, parallel to studies under natural conditions, we plan to develop experiments under controlled conditions, such as those described above, to contribute to the analysis of parameters of the foraging process.

\section{ACKNOWLEDGMENTS}

The authors would like to thank Dr JL Deneubourg (Université Libre, Bruxelles) for fruitful discussions on data interpretation. 
Résumé - Étude du comportement de butinage en fonction de l'âge chez l'abeille domestique en conditions artificielles. La distribution des tâches en fonction de l'âge chez les ouvrières d'abeilles est bien connue, l'activité de butinage apparaissant chez les ouvrières les plus âgées. Cependant peu d'études ont porté sur la division de l'activité de butinage au sein d'une population d'ouvrières en âge de butiner. Afin d'analyser cet aspect, nous avons observé en cage de vol, le comportement de butinage d'ouvrières appartenant à 4 classes d'âge (classes I à IV comprises dans une période de 2 semaines). Les butineuses sont repérées individuellement sur une source alimentaire odorante (solution de saccharose associée à du géraniol) distribuée ad libitum durant des périodes d'observation quotidiennes de $2 \mathrm{~h}$, pendant 22 jours. Les butineuses de la classe I sont les mieux représentées sur la source $(30 \%$ des ouvrières de cette classe butinent, contre moins de $13 \%$ dans les autres classes) (fig 1), et elles effectuent le pourcentage de visites le plus élevé durant la première moitié de la période d'observation, avant d'être relayées par les autres classes. A l'échelle individuelle, indépendamment de la classe d'âge, les butineuses réalisent le même nombre de visites à la source $(4,74$ visites par individu par jour d'observation) (fig 2). Toutefois, une grande variabilité apparaît dans la fidélité des individus à la source alimentaire : sur 84 butineuses observées durant 22 jours, 19 sont présentes 1 seul jour, 6 à 12 butinent de 2 à 6 jours, les autres prolongeant leurs visites de 6 à 18 jours (fig 3). Ces résultats soulignent l'intérêt d'expérimentations conduites en conditions artificielles qui, menées en parallèle à des observations en conditions naturelles, devraient permettre de mieux définir les limites de ta flexibilité dans la division du travail chez l'abeille.
Apis mellifica (ligustica $x$ caucasica) $x$ mellifica / butinage / effet âge / division du travail / chambre de vol

\section{Zusammenfassung - Altersbezogenes} Sammelverhalten bei Honigbienen und künstlichen Bedingungen. Die Arbeitsteilung bei den Arbeitsbienen in Abhängigkeit von ihrem Alter ist gut bekannt; die Sammeltätigkeiten treten bei den ältesten Bienen auf. Es gibt jedoch noch wenige Untersuchungen, die sich mit der Teilung der Sammeltätigkeit innerhalb einer Arbeiterinnen-Population im Sammelalter beschäftigen. Um diesen Aspekt zu analysieren, haben wir das Sammelverhalten von Arbeitsbienen in einem Flugkäfig beobachtet, die zu vier Altersklassen gehörten (Klasse I-IV, innerhalb einer Periode von zwei Wochen). Die Sammlerinnen wurden individuell an einer mit Duft versehenen Futterstelle (Saccharoselösung mit Geraniol) gezeichnet, die während der Versuchsdauer von 22 Tagen zur täglichen Beobachtungszeit von $2 \mathrm{~h}$ ad libitum versorgt war. Die Sammlerinnen der Klasse I waren an der Futterstelle am besten vertreten (30\% der Arbeiterinnen dieser Klasse sammelten, gegenüber weniger als $13 \%$ bei den übrigen Klassen, Abb 1), und sie hielten während der ersten Hälfte der Beobachtungsperiode den höchsten Anteil an Besuchen, bevor sie zu gleichen Teilen von den anderen Klassen abgelöst wurden (Abb 2). Bei Bewertung jeder Biene für sich, unabhängig von der Altersklasse, führte jede Sammlerin dieselbe Zahl von Besuchen der Futterstelle durch $(4,74 \mathrm{Be}$ suche/Individuum/Beobachtungstag; Abb 3). Es ist jedoch eine große Variabilität in der Stetigkeit des Besuchs an der Futterstelle durch die einzelnen Bienen festzustellen: Von 84 Sammlerinnen, die während der 22 Tage beobachtet wurden, zeigten sich 19 nur an einem einzigen Tag, 6 bis 
12 sammelten an 2 bis 6 Tagen, während die übrigen ihre Besuche auf 6 bis 18 Tage ausdehnten (Abb 4). Diese Ergebnisse unterstreichen die Bedeutung von Experimenten, die unter künstlichen $\mathrm{Be}$ dingungen durchgeführt werden, weil sie es besser gestatten, zusammen mit Beobachtungen unter natürlichen Bedingungen, die Grenzen der Flexibilität in der Arbeitsteilung der Bienen zu bestimmen.

\section{Apis mellifera (ligustica $x$ caucasica) $x$ mellifera / Sammeltätigkeit / Altersein- fluß / Arbeitsteilung / Flugraum}

\section{REFERENCES}

Cornuet JM, Fresnaye J (1979) Production de miel chez des hybrides interraciaux d'abeilles (Apis mellifica L) lors de générations successives de rétrocroisements sur la race locale. Apidologie 10, 3-15

Douault P (1978) L'élevage expérimental des abeilles en milieu clos. Bull Tech Apic OPIDA 5, 15-22

Fresnaye J, Lavie $P$, Boesiger E (1974) La variabilité de la production de miel de l'abeille de race noire (Apis mellifica mellifica) et chez quelques hybrides interraciaux. Apidologie 5 , $1-20$

Frisch von $\mathrm{K}$ (1967) The Dance Language and Orientation of Bees. Cambridge (MA), Harvard University Press, 566

Fukuda H, Sekiguchi K (1966) Seasonal change of the honey bee worker longevity in Sapporo, North Japan, with notes on some factors affecting the life span. Jpn $J$ Ecol 16, 206212

Kolmes SA (1985) A quantitative study of the division of labour among worker honey bees. $Z$ Tierpsychol 68, 287-302

Kolmes SA, Winston ML (1988) Division of labour among worker honey bees in demographically manipulated colonies. Ins Soc 35 (3), 262-270

Lindauer $M$ (1953) Division of labour in the honey bee colony. Bee World 34, 63-73; 85-90

Lindauer M (1961) Communication Among Social Bees. Cambridge (MA), Harvard University Press, 243

Michener CD (1974) The Social Behavior of the Bees. Cambridge (MA), Harvard University Press, 404
Nunez JA (1970) The relationship between sugar flow and foraging and recruiting behaviour of honey bees (Apis mellifera L.). Anim Behav $18,527-538$

Pham-Delegue MH, Masson C (1985) Analyse par conditionnement associatif du mécanisme de la reconnaissance de sources alimentaires par l'abeille. Bull Soc Entomol France 90, 1216-1223

Pham-Delegue $\mathrm{MH}$, Masson $\mathrm{C}$, Douault $\mathrm{P}$ (1984) Etude comparée effectuée au laboratoire, des aptitudes au butinage d'abeilles de race Apis mellifica ligustica et d'hybrides interraciaux Apis mellifica (ligustica $x$ caucasica $\times$ mellifica). Apidologie 15, 33-42

Ribbands CR (1952) Division of labour in the honeybee community. Proc $R$ Soc Lond Ser $B 140,32-42$

Ribbands CR (1954) Communication among honeybees. I. The response of crop-attached bees to the scent of their crop. Proc $R$ Soc Lond Ser A 29, 10-12

Rösch GA (1925) Untersuchungen über die Arbeitsteilung im Bienenstaat, I. $Z$ Vergl Physiol 2, 571-631

Rösch GA (1930) Untersuchungen über die Arbeitsteilung im Beinenstaat, II. $Z$ Vergl Physiol 12, 1-71

Seeley TD (1982) Adaptative significance of the age polyethism schedule in honeybee colonies. Behav Ecol Sociobiol 11, 287-293

Seeley TD (1983) Division of labor between scouts and recruits in honey bee foraging. Behav Ecol Sociobiol 12, 253-259

Sekiguchi K, Sakagami SF (1966) Structure of foraging population and related problems in the honeybee, with considerations on the division of labor in bee colonies. Rep Hokkaido Natl Agric Exp Stn 69, 1-65

Waller GD (1972) Evaluating responses of honeybees to sugar solutions using an artificial flower feeder. Ann Entomol Soc Am 65, 857861

Wenner AM, Wolls PH, Rohlf FJ (1967) An analysis of the waggle dance and recruitment in the honey bees. Physiol Zool 40, 317-344

Winston ML, Punnet EN (1982) Factors determining temporal division of labor in honeybees. Can J Zool 60, 2947-2952

Winston ML, Fergusson LA (1985) The effect of worker loss on temporal caste structure in colonies of honeybee (Apis mellifica L). Can $\checkmark$ Zool 63, 777-780 